\title{
PROBLEM-BASED TASKS IN FOREIGN LANGUAGE ACQUISITION FOR INTENDING EDUCATORS
}

\author{
Natalia Dmitrenko \\ Vinnytsia Mykhailo Kotsiubynskyi State Pedagogicl University, Ukraine \\ Anastasiia Petrova \\ Vinnytsia Mykhailo Kotsiubynskyi State Pedagogicl University, Ukraine \\ Olena Podzygun \\ Vinnytsia Mykhailo Kotsiubynskyi State Pedagogicl University, Ukraine
}

\begin{abstract}
The problem-based learning of a foreign language is aimed to develop students' creativity, increase their motivation, autonomy, experience future profession tasks, and improve cognitive and communicative skills.

The purpose of the article is to justify the efficiency of forming communicative skills of intending educators by means of problem-based tasks within the discipline "English for Professional Communication". The objective of the article is to report about the results of using problembased tasks in students' acquisition of course content and in formation of students' linguistic competence.

In order to test the theoretical statements of using problem-based tasks in foreign language acquisition, a diagnostic experimental study was conducted. It was aimed at identifying cognitive-communicative needs and opportunities of students in solving problem tasks. The study included: experimental training, diagnostic tests and questionnaires for students and teachers. As a result, the cognitive and communicative needs and opportunities of students to solve problem tasks were determined; the prospects of application of problem tasks in the development of creative thinking in the process of formation and development of skills of foreign language communication were revealed.

The experiment data enable to conclude that regular using of problem-based tasks marked positive impact on formation of students' linguistic competence. Phonetic, lexical and grammatical skills have improved due to communication with peers and self-control during solving problem tasks. The overall results of the study affirm the enhancement of students' speaking skills (monologue, dialogue, polylogue skills).
\end{abstract}

Keywords: foreign language, higher education, intending educators, problem-based tasks.

\section{Introduction}

The new realities of the professional activities of modern teachers require a quick and effective reform of the higher pedagogical education. Searching for other approaches to the organization of the educational process in higher educational institutions, updating of methods and forms of training, development 
and implementation of new educational technologies in the educational process is urgent in the current situation.

In the professional activity and everyday life of any person there are certain difficulties, obstacles, unexpected situations, problems that need to be overcome and solved. This, in turn, requires intellectual and creative efforts, awareness in various sectors of life, a deeper acquaintance with the outside world, the discovery of new phenomena, processes, properties, the relationship of a person with everyday things, and lately, there is a need for knowledge of at least one foreign language. It is due to the fact that more and more people of different ages, professions and interests are getting involved in communication in a foreign language. Therefore, the main goal for the youth is to master a foreign language as a means of communication at the intercultural level. This task is a challenge today due to the modern realities of the world, which is becoming increasingly global. Problem-based learning is obliged to ensure the formation and further development of foreign communicative competence of intending educators.

Taking into consideration the given information, the aim of the proposed article is to justify the efficiency of forming communicative skills of intending educators by means of problem-based tasks within the discipline "English for Professional Communication" and analyse the results of using problem-based tasks in students' acquisition of course content and in formation of students' linguistic competence.

\section{Literature review}

Problem-based Learning (PBL) was first introduced by Barrows in medical education in the mid 1950's and later spread to other fields, specifically business and social studies. According to Barrows (2002), problem-based learning is a learning method based on the principle of using real-world problems as a starting point for the acquisition and integration of new knowledge.

Torp and Sage (2002) consider PBL as a focused, experiential learning organised around investigation and resolution of messy and real-world problems. Teachers use real-world problems as they coach learning through probing, questioning, and challenging students' thinking.

PBL is a learning approach that seeks to create a link between theoretical knowledge and practice. It is essential to have collaborative groups in learning contexts; to explore, analyze and solve the problems presented (Cockrell \& Caplow, 2000). Students are expected to be able to organize their lives, studies and learning in a manner which prepares them for their chosen profession (Armstrong, 2012). Moreover, when students work on solving problem cases or situations, the activities involved tend to trigger motivation and engagement (Bosuwen \& Woodrow, 2009). 
Larsson (2001) stated that students in PBL classrooms improve their social skills as they have more opportunities to practise using the language for authentic communication. Besides, students gain a deeper understanding when the vocabulary is encountered in real-world situations.

Nowadays the PBL method helps to create meaningful ESL activities. The problem solving process in PBL requires students to look for materials and to constantly relate what they read to what to do with the information (Torp \& Sage, 2002). Watson (2001, p.3) explains that in PBL, "students work with classmates to solve complex and authentic problems that help develop content knowledge as well as problem-solving, reasoning, communication, and self-assessment skills". This enables the students to integrate content knowledge with their knowledge of a foreign language.

We share the opinion of Legg (2007) that PBL appears to be a suitable approach to be implemented in the English language classroom in universities to enhance teaching and learning of English.

Overall, the literature review highlights PBL as an effective learning tool in general, and for foreign language acquisition in particular. However, despite its efficiency, the empirical research on PBL for foreign language acquisition in training of intending educators is limited.

\section{Methodology}

In order to verify the theoretical positions on the possibility of using problem-based learning for the development of foreign language communication skills, the diagnostic study was performed, which was aimed at identifying the cognitive-communicative needs and capabilities of students in solving problembased situations. The experimental training was carried out on the basis of a monograph (Dmitrenko, 2017) and a textbook (Dmitrenko, Petrova, \& Podzygun, 2019) on the implementation of problem-based learning created by the educators of the Department of Methodology of Foreign Language Teaching at Vinnytsia Mykhailo Kotsiubynskyi State Pedagogical University (Ukraine) for the discipline "English for Professional Communication".

Studying the issue of implementing problem-based situations in the development of foreign language communication skills, we consider it appropriate to reveal the concept of problem-based tasks in the formation of linguistic competence, namely: grammatical, lexical and phonetic.

Problem-based tasks for the formation of grammatical competence should contain examples of linguistic phenomena that students analyze, generalize certain facts and independently formulate grammatical rules. Thus, the cognition occurs from the particular to the general. 
Having analyzed the scientific and methodological literature (Dmitrenko, 2016a; Harmer, 2010), the following problem-based tasks are used at different stages of mastering grammatical competence, namely:

- the tasks related to the preliminary demonstration of grammatical phenomena in texts for reading or listening (read / listen to the text and define which grammatical construction is most often found in it);

- $\quad$ the tasks for comparing various parts of sentences or expressions (work out the examples of various constructions, compare parts of a sentence, taking into account the principles of their construction, which are given in the examples);

- the text processing in order to analyze grammatical phenomena (analyze the grammatical structures used in the text, define their form, meaning, usage);

- a solution to a grammatical problem (find identical grammatical phenomena among similar ones, compare similar phenomena and define the difference between them, correct grammatical errors).

When modeling these problem-based situations, it is necessary to take into account the capabilities of students, the stages of the grammatical skills formation and the peculiarities of grammatical material.

Problem-based tasks which focus on forming lexical competence may include the following samples:

- $\quad$ tasks for selecting lexical units identical in content among similar ones (find absolute synonyms in the list of words);

- tasks for comparing similar lexical units and finding the difference between them (compare the following synonyms and define the difference between them);

- $\quad$ tasks for the classification of lexical material (classify vocabulary by four parameters, define the principles for its classification);

- $\quad$ verbal riddles (guess what is described in the text);

- $\quad$ tasks to complete rhymes (fill in the gaps in verses with the words suitable for the rhyme);

- tasks involving the decoding of figurative-schematic information (define what is encrypted in the puzzles);

- $\quad$ tasks for searching of linguistic equivalents (study the proposed words and expressions, give examples of equivalents in English) (Dmitrenko, Petrova, \& Podzygun, 2019).

During phonetics training, it is possible to implement problem-based tasks that include the classification of phonetic material, a comparison of similar phonetic phenomena and finding the difference between them, the search of identical phonetic phenomena among similar ones. 
The implementation of the grammar, lexical, phonetic problem-based tasks described above contributes to making the correct choice of linguistic means, the competent use of various language means, makes it possible to understand the sociolinguistic features of their use, and therefore ensures the development of foreign language communication skills (Dmitrenko \& Petrova, 2017).

In the context of studying a foreign language, the main properties of problem-based tasks include: authentic communication in class; relevance of the assignment for participants; the complexity of the task; informational inequality of partners (participants with different interests, different hobbies complement each other); creative character (Dmitrenko, 2017).

Assessing the results of problem-based tasks, the teacher needs to understand the assessment criteria clearly and explain them to students first. The main assessment criteria for accomplishing problem-based tasks in foreign language classes can be: the degree of solving the problem, the organization of the text, interaction with interlocutors, as well as vocabulary, grammar, spelling, punctuation, and pronunciation.

The criteria depend on a type of the task, and the teacher can choose the most important in the particular case. An important condition is involving students in the discussion and assessing the other students. Thus, they acquire valuable skills in assessing their own answers; they understand better the requirements of the teacher and the rules of giving grades, which they will need during teaching practice and future professional activities.

In order to develop students' foreign language communication skills outside the linguistic environment, it is not enough to complete classes with communicative exercises that allow solving communicative tasks. It is important to invite students to think, solve problems that provoke thoughts, thinking on possible ways to solve the problems, so that students focus on the content of the statement. In such a way a thought is in the center of the attention, and language acts in its direct function of the formation and formulation of these thoughts (Dmitrenko, 2016a).

\section{Methods}

\section{Participants}

In order to verify the theoretical substantiations on the possibility of using problem-based teaching methods for the formation and development of foreign language communication skills, a diagnostic experimental training was provided. The experimental training was conducted at Vinnytsia Mykhailo Kotsiubynskyi State Pedagogical University (Ukraine) with the first-year students of specialties Secondary Education (Mathematics), Secondary Education (History), Psychology, Primary education in term II during 2018-2019 academic year. 60 
students participated in the experimental training while studying the discipline "English for Professional Communication", who were randomly assigned into control and experimental groups. Each group consisted of 30 students. 80-min periods were conducted twice a week for 1 term (17 weeks). The participants of the experimental study were informed about the purpose and the structure of research and assured that their names would not be used in the study result reports.

\section{Instruments}

In the study, two instruments were used: Preliminary English Test (PET) (Cambridge Assessment English) and the Programme Evaluation Questionnaire (Dolmans, D.H. Wolhagen, J.M., \& van der Vleuten C.P.M., 1998).

The preliminary and final English tests of speaking, taken from Preliminary English Test (PET), were given to the students to witness the initial and final level of students' speaking skills (monologue, dialogue, polylogue skills). The total maximum practice test score is 30 (30-28 - very high level, 27-20 - high level, 19-13 - moderate level, 12-6 - low level, 5-1 - very low level).

The Programme Evaluation Questionnaire consisted of two sections. The statements of section one (10 items) were concentrated on evaluating the influence of the problem-based tasks on the learning process. The statements of section 2 (5 items) were focused on distinguishing language skills development. The survey was used in the experimental group to detect the students' views about the use of problem-based tasks in the language learning process. In the instruction, the students were asked to estimate the degree of their agreement with the test statements, assessing them from one to five points (a five-point Likert scale): 5 - means completely true (strongly positive); 4 - means usually true (positive); 3 - means sometimes true (uncertain/neutral); 2 - means not usually true (negative); 1 - means never true (strongly negative). The score range of the questionnaire is the following: 5.00-4.51 means that the level of students' perception of the problem-based tasks and students' perceived impact of problembased tasks on language skills is very positive, 4.50-3.51 - positive, 3.50-2.51 neutral, 2.50-1.51 - negative, 1.50-1.00 - very negative.

The textbook "Use of problem-based tasks in classes of the discipline "Foreign language for professional communication (English)" of intermediate level was used among other programme learning materials (Dmitrenko, Petrova, \& Podzygun, 2019).

\section{Research Design}

The study included the experimental training, English tests of speaking proficiancy, a two-section questionnaire.

At the initial phase the students of both groups were asked to do English test (Speaking Section of PET) to evaluate the level of their communicative skills. 
At the experimental phase the educational problem-based tasks were used in the foreign language classes of the experimental group. The teachers adhered to a certain sequence of their organization. We proposed to use the following algorithm for creating and implementing problem situations.

1. The preparatory stage. The teacher instructs students to complete a problem-based task that creates a problem situation.

2. The discussion stage. Students work in small groups or in pairs, thinking over several possible solutions to the problem compare them and choose one for discussion by the whole group, explaining why they chose it.

3. Written stage No 1. After discussion in a group, students write their individual plan for solving the problem, taking into account the results of the discussion stage.

4. Written stage No 2. A unified plan for solving the problem is created. If the problem was authentic and its solution has social significance, then a plan for solving this problem can be proposed to a certain specialized organization or published in the university newspaper.

5. Analysis of selected language tools. The use of language tools and the final solution to the problem-based situation are taken into account.

For the formation and improvement of speech skills, the following problembased tasks at the experimental phase were used: tasks for reproducing a situation, role-playing games of a problem nature, scenarios, simulations, discussions, projects.

The students of control group were taught by a traditional teacher-based method.

At the final phase the students of both groups were given English Speaking Test (PET) in order to evaluate the level of their communication skills after the experimental training and to compare the test results of initial and final phases. The students of the experimental group were asked to fill in a two-section questionnaire.

The data for this article is taken from the experimental group that underwent problem-based tasks during the experimental training.

\section{Results}

A comparison of the preliminary and final English test (Speaking PET) showed that at the initial phase the results of the two groups differ insignificantly but at the final phase the students of the experimental group obtained higher scores (Table 1). At the initial phase students of both groups demonstrated the moderate level of knowledge. At the final phase the students of the experimental group acquired higher scores in comparison with results of the control group and own 
Dmitrenko et al., 2020. Problem-Based Tasks in Foreign Language Acquisition for Intending Educators

results of the initial phase. The students of experimental group obtained a high level ( $\mathrm{M}=50.58)$ of speaking skills (monologue, dialogue, polylogue skills).

Table 1 Results of Preliminary and Final English Tests

\begin{tabular}{|l|c|c|}
\hline & Control Group & Experimental Group \\
\hline Preliminary & $\mathrm{N}(30)$ & $\mathrm{N}(30)$ \\
\cline { 2 - 3 } English & $\mathrm{M}=16.81$ & $\mathrm{M}=17.05$ \\
Test & $\mathrm{SD}=4.33$ & $\mathrm{SD}=4.85$ \\
\hline Final & $\mathrm{M}=16.32$ & $\mathrm{M}=20.58$ \\
English Test & $\mathrm{SD}=4.25$ & $\mathrm{SD}=5.05$ \\
\hline
\end{tabular}

The students of the experimental group were asked to respond to a twosection questionnaire modified from the Programme Evaluation Questionnaire (Dolmans, D.H. Wolhagen, J.M., \& van der Vleuten, C.P.M., 1998). In our study the reliability coefficient (Cronbach Alpha) value for a two-section questionnaire was calculated to estimate the internal consistency. It was found to be quite high: 0.85 .

Table 2 Mean Scores and Standard Deviation of a two-section questionnaire

\begin{tabular}{|l|c|c|c|}
\hline \multicolumn{1}{|c|}{ Description } & $\boldsymbol{M}$ & SD & Interpretation \\
\hline $\begin{array}{l}\text { Section 1: Students' Perceptions of the Effectiveness of } \\
\text { Problem-based Tasks on Language Learning }\end{array}$ & & & \\
\hline $\begin{array}{l}\text { The problem-based tasks allowed application of learning to } \\
\text { real life situations }\end{array}$ & 4.65 & 0.43 & very positive \\
\hline The problem-based tasks promoted working with others & 4.57 & 0.41 & very positive \\
\hline $\begin{array}{l}\text { The problem-based tasks stimulated continuous acquisition of } \\
\text { new and relevant knowledge }\end{array}$ & 4.45 & 0.63 & positive \\
\hline Overall, I am satisfied with the problem-based tasks & 4.31 & 0.66 & positive \\
\hline Overall, my learning experience was stimulating & 4.27 & 0.68 & positive \\
\hline I participated actively in my group meetings & 4.18 & 0.71 & positive \\
\hline $\begin{array}{l}\text { I was motivated to learn and use English throughout the } \\
\text { process of solving problem-based tasks }\end{array}$ & 4.14 & 0.74 & positive \\
\hline I could find the learning resources for the problem-based tasks & 4.01 & 0.65 & positive \\
\hline I was motivated to manage the problem & 3.93 & 0.68 & positive \\
\hline I had sufficient time to manage the problem-based tasks & 3.84 & 0.55 & positive \\
\hline \multicolumn{1}{|c|}{ Average } & 4.23 & 0.61 & positive \\
\hline Section 2: Students' Perceived Impact of Problem-based & & & \\
\hline Self-confidence in using the language & 4.41 & 0.51 & positive \\
\hline Presentation skills & 4.35 & 0.56 & positive \\
\hline Communicating with peers (communicative skills) & 4.28 & 0.58 & positive \\
\hline Problem-solving skills & 4.24 & 0.61 & positive \\
\hline Speaking skills & 4.18 & 0.64 & positive \\
\hline & 4.29 & 0.58 & positive \\
\hline
\end{tabular}


The table 2 shows the mean scores, standard deviation and interpretation of the results of a two-section questionnaire which was completed by 30 students of the experimental group.

Table 2 shows the results of the statistical analysis of the two examined sections of the questionnaire. In general, the students have positive perceptions of the effectiveness of problem-based tasks $(\mathrm{M}=4.23)$ and positive perceived impact of problem-based tasks on language skills $(\mathrm{M}=4.29)$ as well.

The most significant mean value among the ten items of section 1 is that the problem-based tasks allowed application of learning to real life situations $(\mathrm{M}=4.65)$. The highest mean value of section 2 is self-confidence in using the language $(\mathrm{M}=4.41)$. The data on the categories do not vary substantially.

As it is clear from table 2, most values of standard deviation (SD) lie in the range 0.41-0.74. It signifies that the data points tend to be close to the mean of the set, i.e. the answers are more or less homogeneous.

To ascertain whether the obtained results in the experimental group are obvious statistically and how variables (grades of English test and scores of a twosection questionnaire) are correlated, we applied Pearson's correlation coefficient: $r=0.8957$. The positive correlation shows a strong relationship between the two variables. The $p$-value is 0.427 that signifies a noticeable correlation between variables. The results suggest that using problem-based tasks procedure could be helpful in predicting high level of English proficiency.

\section{Discussion}

Evidence-based, we have found out that regular using of problem-based tasks helped students achieve better results in their language proficiency. The implementation of problem-based tasks in foreign language classes reorients the educational process from dry, ineffective memorization of vocabulary and grammar, which has traditionally been the basis of teaching a foreign language at a university, to the realization of communication intentions.

The results of the survey show that, on the whole, the students have positive perceptions of the effectiveness of problem-based tasks. The problem-based tasks allowed application of learning to real life situations, promoted working with others, and stimulated continuous acquisition of new and relevant knowledge. The students are satisfied, motivated and participate actively in group meetings. The findings of this study go in line with the results reported by other researchers (Torp \& Sage, 2002; Sungur \& Tekkaya, 2006). Problem-based learning in the classroom is effective if problem-based tasks affect the students; involves the use of the personal life experience (family relationships, hobbies, youth problems). The experience shows that it is possible to bring problem-based tasks closer to 
real communication not only due to life situations, but also by increasing the novelty of information, which undoubtedly arouses interest in students.

The students' perceived impact of problem-based tasks on language skills is also rather positive. The students of the experimental group demonstrate high level of self-confidence in using the language, presentation skills, communicating with peers (communicative skills), problem-solving skills, speaking skills. The same results of positive perceived impact of problem-based tasks on language skills were proved by other studies (Barrows, 2002; Sunger \& Takkaya, 2006; Azman \& Shin, 2012). We agree with the opinion of scholars that problem-based learning involves the use of new methods and techniques in the educational process, revitalizes and activates them, eliminates thoughtless memorization and retelling of "book" knowledge, attracts active thinking, creative independence in the process of cognizing the world.

\section{Study Limitations}

As the size of the sample is rather small, the survey results cannot be generalized as the sample $(n=60)$ selected cannot exemplify the entire population at large. Rather, this study should be considered as an exploratory investigation that has the goal of identifying possible issues and trends for further research.

\section{Conclusions}

The study provides some insights into the importance of using the PBL approach in the ESL classroom while training intending educators. The results show that regular using of problem-based tasks marked positive impact on formation of students' linguistic competence. Phonetic, lexical and grammatical skills have been improved due to communication with peers and self-control during solving problem tasks. The overall results of the study affirm the enhancement of students' speaking skills (monologue, dialogue, polylogue skills). The intending educators who performed problem-based tasks presented their arguments in a proficient manner, provided sufficient supporting material to illustrate their arguments, used relevant language clichés and grammar structures, and at the same time acquired course content. The other positive effects of using problem-based tasks for intending educators included improved critical thinking, problem-solving skills in the future profession area, fluency in the foreign language, and cooperation.

The results of the experimental training demonstrated the difference between methods of problem-based learning and the traditional ones. Problem methods put students in the position when they are forced to think actively and intensively, mobilizing their intellectual potential to solve the problem and form a theoretical 
conclusion. Thus, the methods of problem-based learning in English classes complement the traditional illustrative and explanatory teaching of students. At the same time, they contribute to the destruction of old stereotypes of passive learning, make students think, seek answers to complex vital questions together with the teacher.

It is worth noting that the use of problem-based tasks in foreign language classes stimulates the personal activity of students, which provides an initiative in the formation and development of foreign language communication skills, systematic and persistent cognitive actions, and, above all, a positive result in training and education.

Thus, problem-based tasks can be applied in foreign language classes, teaching all types of speech activity and aspects of the language, and, accordingly, developing students' foreign language communication skills.

\section{References}

Armstrong, J.S. (2012). Natural Learning in Higher Education. In Encyclopedia of the Sciences of Learning (1-10). Philadelphia, PA: University of Pennsylvania.

Azman, N., \& Shin, L. (2012). Problem-based Learning in English for a Second Language Classroom: Students' Perspectives. International Journal of Learning, 18, 109-126. DOI: 10.18848/1447-9494/CGP/v18i06/47648.

Barrows, H.S. (2002). An overview of authentic problem-based learning (APBL). In Wee, K. N.L., \& Kek, Y.C.M. (Eds.), Authentic problem-based learning: Rewriting business education. Jurong, Singapore: Prentice Hall Asia Pte. Ltd.

Berns, R.G., \& Erickson, P.M. (2001). Contextual teaching and learning: Preparing students for the new economy. The Highlight Zone: Research @Work, 5, 2-9. Retrieved from ERIC Document Reproduction Service No. ED 452376.

Bosuwon, T., \& Woodrow, L. (2009). Developing a Problem-Based Course Based on Needs Analysis to Enhance English Reading Ability of Thai Undergraduate Students. RELC Journal, 40-64.

Cockrell, K.S., \& Caplow, J.A.H. (2000). A Context for Learning: Collaborative Groups in the Problem-Based Learning Environment. The Reviews of Higher Education, 23(3), 347. DOI: https://doi.org/10.1353/rhe.2000.0008

Dmitrenko, N. (2016a). Problem-based learning as a learner-centred approach: general review. Proceedings of the international conference "Modern peculiarities of the identity formation and social adaptation in conditions of liberal values crisis”, 9.02.2016. 15.02.2016, (21-24), London: IASHE.

Dmitrenko, N. (2016b). The implementation of problem-based learning in Ukrainian higher educational institutions. Advanced Education, 5, 28-35.

Dmitrenko, N.Ye. (2017). Problem-based learning in teaching English as a foreign language: theoretical and practical issues: monohraph. Vinnytsia: FOP T. P. Baranovs'ka.

Dmitrenko, N.Y., \& Petrova, A.I. (2017). Zastosuvannya problemnykh sytuatsiy dlya formuvannya inshomovnoyi komunikatyvnoyi kompetentnosti u maybutnikh uchyteliv na zanyattyakh $\mathrm{z}$ anhliys'koyi movy [Use of problem-based situations for the formation 
Dmitrenko et al., 2020. Problem-Based Tasks in Foreign Language Acquisition for Intending Educators

of foreign language communicative competence of future teachers in English classes]. Inozemni movy, 3, 23-30.

Dmitrenko, N.Y., Petrova, A.I., \& Podzygun, O.A. (2019). Zastosuvannya problemnykh zavdan' na zanyattyakh z dystsypliny “Inozemna mova dlya profesiynoho spilkuvannya (anhliys'ka) [Use of problem-based tasks in classes of the discipline "Foreign language for professional communication (English)": textbook]. Vinnytsia, VDPU.

Dmitrenko, N., \& Dolia, I. (2016). Zastosuvannya problemno-oriyentovanoho navchannya na zanyattyakh z inozemnoyi movy u vyshchomu navchal'nomu zakladi [Use of problemoriented learning in English classes at a higher education institution]. Modern informational technologies and innovative methods in professional training: methodology, theory, experience, problems, 46, 166-170.

Dolmans, D.H.J.M., Wolhagen, \& van der Vleuten, C.P.M. (1998). Tutor intervention profile: reliability and validity. Medical Education, 32, 262-268.

Harmer, J. (2010). How to Teach English. Sixth impression, Pearson Education Limited.

Larsson, J. (2001). Problem-based learning: A possible approach to language education. Retrieved from https://www.nada.kth.se/ jla/docs/PBL.pdf

Legg, M. (2007). From question to answer: The genre of the problem-based learning tutorial at the University of Hong Kong. English for Specific Purposes, 26, 344-367.

Sungur, S., \& Tekkaya, C. (2006). Effects of problem-based learning and traditional instruction on self-regulated learning. Journal of Educational Research, 99(5), 307-317.

Torp, L., \& Sage, S. (2002). Problems as possibilities: Problem-based learning for K-16 education. 2nd (Ed). Alexandria, Virginia USA: Association for Supervision and Curriculum Development.

Watson, G. (2001). Problem-based learning. Speaking of Teaching, 11(1), 1-7. 